Vol. 7(1), pp. 001-006, January, 2018

Copyright (C2018, the copyright of this article is retained by the author(s)

http://gjournals.org/GJEMPS

\title{
Influence of Conservation Education Advocacy on Career Attractiveness among the Youths in South-South Nigeria: Boki, Cross River State Experience
}

\section{Koko Sunday DANIEL ${ }^{1 *}$; Emem Bassey INYANG ${ }^{2}$ and Edisana Emmanuel ITUEN ${ }^{1}$}

\footnotetext{
${ }^{1}$ Department of Forestry and Natural Environmental Management, University of Uyo, Uyo. ${ }^{2}$ Department of Agricultural Economics and Extension, University of Uyo. Uyo.
}

\section{ARTICLE INFO}

Article No.: 122017179

DOI: $10.15580 / G J E M P S .2018 .1 .122017179$

\section{Submitted: 20/12/2017}

Accepted: $27 / 12 / 2017$

Published: 31/01/2018

*Corresponding Author

Koko Sunday Daniel

E-mail: kokodaniel@uniuyo.edu.ng Phone: +2348023858245

Keywords: Attitudinal Disposition, Environment, Impact Profile, Programme
This study was designed to evaluate the influence of conservation education advocacy on the youths with regards to career attractiveness. The study adopted a two - stage sampling technique in selecting one hundred and fifty seven (157) respondents from three secondary schools within the operational base of the PANDRILLUS FOUNDATION. The results indicated that majority $(49.7 \%)$ of the respondents were in Senior Secondary Two (SS2), $59.2 \%$ of the respondents were male while $52.2 \%$ were within the age bracket of 17 - 19years.

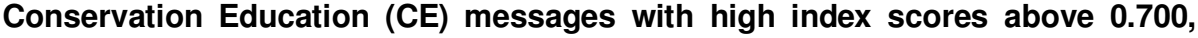
profiled by the respondents included impact of deforestation, agroforestry, afforestation/ enrichment planting, land rotation, and global warming/ climate change. Over $75 \%$ of the respondents professed that the conservation education has positive impact on them, $99.4 \%$ of the sampled respondent showed attitudinal deposition towards career in environmental conservation related discipline. Environmental management, Forestry, Horticulture and landscaping, Veterinary medicine, and Wildlife conservation/management, had well above $50 \%$ embrace by the respondents. Development of environmental extension programme, use of methods that motivate listenership and programme evaluation were among the recommendations advanced to enhance the efficiency of governmental and nongovernmental institutions involve in environmental management. 


\section{INTRODUCTION}

Nigeria's biodiversity, its habitats and other natural ecosystems such as sacred groves, water catchment areas, and wetland are increasingly coming under intense pressure and threat of extirpation (local extinction). The pressure is as a result of an increasing human population, changing land uses (industrialization, urbanization, farming) and the ever- increasing need for goods and services from the ecosystems (DANIEL et al., 2016; THOMPSON, 2002; EZEBILO, 2010; DAYE and HEALEY, 2015). Nigeria has been working with its partners over the years to conserve this natural wealth, but the desired shift in the disposition of the rural dwellers seems unchanged. Throughout the 1990s and into this century, evidences have been documented of agricultural encroachment, illegal logging, and commercial hunting for bush meat in protected areas (OATES, 1999). The Cross River National Park (CRNP) and their partners from non-governmental organizations (NGOs), is not immune and continue to face the resource exploitation pressure.

STONE and D' ANDREA (2001) asserted that most international institutions and national governments have been unable to stem the accelerating loss of tropical forest lands due to reasons like unarticulated development strategy and poor environmental education. They highlighted one solution for preserving the precious resources of the forest: empowerment of local people who depend on the forest for survival.

Using this template, the Cross River State Government, PANDRILLUS FOUNDATION and the Buanchor Community in Boki Local Government Area agreed to collaborate on rural development and conservation. The Cross River State paid compensation in cash to households whose lands are alienated and also provided electricity, portable water, healthcare center, functional primary and secondary school while PANDRILLUS pays annual royalty in dollars to Buanchor Community and ensures periodic rehabilitation of Buanchor - Katabang - Kayang earth road linking Ikom - Obudu - Ranch Highway. The community on their part provides counterpart funds derived from royalties and community tax to partner with Cross River State Poverty Reduction Agency / World Bank to construct and equip a vocational training center for skills acquisition on nonforestry dependent vocations especially eco-tourism (EWAH, 2010; PANDRILLUS FOUNDATION, 2008).

The project uses a multi-faceted approach combining in-situ and habitat protection, captive care and breeding, research, training, small scale development schemes, non- formal education and positive advocacy, all aimed to promote the survival of the Drill monkeys, endangered Cross River gorillas, and ecotourism generally (OATES, 2003; PANDRILLUS FOUNDATION, 2008). The educational component's influence on this project is strategic and critical as it proffers a lot towards the effectiveness and choice of career of the young citizens of the adjoining communities. It is indisputable that learning and obtaining knowledge about nature is important for conservation. According to MORGAN and GRAMANN (1989), wildlife education enables children to understand the importance of including animals in their view of the Earth and had resulted in positive changes in knowledge, attitudes, awareness, and actions toward wildlife. KELLERT and BERRY (1987) had also asserted that higher levels of education and a greater perception on the ecosystem have positive effects on the way humans feel about protecting the environment while BJERKE et al., (1998) reported that increased knowledge and understanding of nature provides a more positive attitude towards carnivores. Through structured educational experiences and activities targeted at varying age groups and population, conservation education enables people to realize how natural resources and ecosystems affects each other and how resources can be used wisely (www.fs.usda.gov).

Amongst the target audience of the FOUNDATION which includes the youths, hunters and local community dwellers, the youths are of great concern since majority of them are still in school and the impacts of current advocacy activities could influence their future engagements. Thus, this research was designed to ascertain whether the level of conservation knowledge successfully imparted by the FOUNDATION on the youths have any relative influence on their career attractiveness towards conservation. Specifically, the study identified the socio economic characteristics of the respondents; analyzed the contents of the extended conservation education by PANDRILLUS FOUNDATION; and assessed the influence of conservation education on the respondents' attractiveness to career towards conservation, since younger minds are believed to be easily oriented on issues than older ones.

\section{LITERATURE REVIEW}

An understanding of the dynamics of forest ecosystem provides people with insight about how human activities will actually affect the ecosystem, and it will also influence the attitude towards the ecosystem and the way local people think about conservation biology. Conservation biology covers a set of integrated knowledge about how we can utilize nature in a sustainable way, (PRIMACK, 2010).

Education certainly is important in shaping peoples' attitudes (KIDEGHESHO et al., 2007), but the elements of interest and ability are the basic factors influencing individuals in their choice of subject while lack of interest leads to low efficiency. STORKSDIECK et al., (2005) had shown that positive outcome occurred on readiness to embrace conservation messages in all three cases of urban public school partnership with: nature centre, exhibition on biodiversity, and hotel water conservation. KRUSE and CARD (2010) also reported increasing score in campers' self-reported knowledge, attitude and behavior, with increasing levels of advocacy. Their result further indicated that campers with previous camp experience had higher knowledge and attitude self- ratings than did those without experiences. Therefore, advocacy can help to develop the critical thinking skills/ interest in a subject and this 
may go a long way to enhance a high performance in any examination result and eventual future interest.

Interestingly, in 1987, the Nigerian Conservation Foundation (NCF) helped to develop and drafted a national conservation education strategy that suggested that the subject be integrated into the primary and secondary schools' curricula. This was not successful because of inadequate resources in most schools in the country but the establishment of Conservation Clubs in many schools appear to be more effective (EZEBILO, 2010). This gave the students the opportunity to learn more about natural environment and how to promote forest and biodiversity conservation (EZEBILO, 2010). Further interest and career development is believed to have been developed during sessions of this extracurricular activity. Conservation education as asserted by MBUGUA (2012) is a necessary management tool to inform and impart knowledge, particularly to local communities as well as enhance indigenous and traditional knowledge that is useful for conservation.

\section{MATERIALS AND METHODS}

The study area was conducted in Boki Local Government Area- the operational base of PANDRILLUS FOUNDATION. Boki is one of the Local Government Areas in Cross River State. It lies approximately between latitude $6^{\circ} 15^{\prime}$ and $6^{0} 25^{\prime}$ North and between longitude $8^{\circ} 55^{\prime}$ and $9^{\circ} 1^{\prime}$ East. It is bounded in the west by Ogoja, in the north by Obudu, in the south by Ikom Local Government Areas, and in the east by the Republic of Cameroon (AGBOR, 2003). The area lies within the tropical high forest vegetation zone with annual rainfall between $3,000 \mathrm{~mm}-3,800 \mathrm{~mm}$ but with a variation increasing from lowland to uphill. Rainy season starts around late March / early April to September with a break in August. The dry season starts from October and ends in March. The mean monthly maximum temperature ranges from $22.2^{\circ} \mathrm{C}$ to $27.4^{\circ} \mathrm{C}$ (ITUEN, 2015; AGBOR, 2003). Boki (also referred to as Nki Tribe) has a population of 186,611 people (NPC, 2006).
It bears an international reputation for being a major commercial centre for forest and international agricultural commodities such as cocoa, coffee, timber, and palm products. All of these products are sourced and supplied for international consumption in the territory, (www.en.wikipedia.org).

A two- stage sampling technique was used in selecting respondents used for the study. at the first stage, three schools were randomly selected by simple random sampling from the nine (9) secondary schools in the LGA, at the second stage sixty (60) students were selected by simple random technique from the pool of Senior Secondary one to Senior Secondary three (SS1 SS3) students in each school. One hundred and fifty seven (157) out of the one hundred and eighty (180) targeted respondents were successfully samples. This gives $87.2 \%$ sampling success. Selected schools were: Commercial Secondary School (CSS), Bateriko; Buentsebe Secondary school (BSS), Wulla; and Commercial Secondary school (CSS), Okwabang. This was to ensure that any sampled student must have spent considerable number of academic years in the area and is able to express his/her self appropriately.

Primary data were collected with the aid of structured questionnaires and was analyzed by descriptive statistics, Incidence Index analysis and relative rank order positioning.

\section{RESULTS AND DISCUSSION}

\section{A. Socio-Economic Characteristics of the Respondents}

Table 1 shows the distribution and Socio economic characteristics of the respondents. Majority of the respondents $(49.7 \%)$ were in senior secondary two (SS2), while most of the respondents $(52.2 \%)$ were within the age bracket of 17 - 19years adjudged to be the late adolescent grade. The table also shows that $59.2 \%$ of the respondents were male.

Table 1: Distribution and socio- economic characteristics of respondents

\begin{tabular}{llll}
\hline $\mathrm{S} / \mathrm{N}$ & Characteristics & Frequency & Percentage (\%) \\
\hline 1. & School &
\end{tabular}




\begin{tabular}{llll} 
& CSS Bateriko & 55 & 35.0 \\
& BSS Wulla & 53 & 33.8 \\
2. & CSS Okwabang & 49 & 31.2 \\
& Class & & \\
& SS1 & 54 & 34.4 \\
& SS2 & 78 & 49.7 \\
3. SS3 & Age & 25 & 15.9 \\
& $14-15$ & & \\
& $16-17$ & 47 & 5.7 \\
& $18-19$ & 78 & 29.9 \\
$4 . \quad$ Sex & 32 & 49.6 \\
& Male & & \\
& Female & 93 & 59.2 \\
\hline
\end{tabular}

\section{B. Beneficiary Awareness Incidence Pattern about the Dissemination of Conservation Topics by PANDRILLUS FOUNDATION}

The subsection explored the areas of extended conservation education by PANDRILLUS FOUNDATION to the students during their outreach program to the schools and when they receive the students on excursion. Out of the 20 topics attested to by the students as areas covered by the FOUNDATION (table 2), analyses identified five major focus indicated by the right-sided alphabetical superscript and summarized as follows: Superscript a - environmental mismanagement impact and mitigations; b - sustainable forest and wildlife management; c - practical/ experimental procedures in natural resource management; $d$ - issues in in-situ wildlife conservation; and e - park management. Higher index means higher rating of reception of the topic and higher impact on the respondents. The highest ranked messages received by the respondents, which had index of above 0.700 were items $8,16,17$, and 20 . All the four items centered on ecological remedies for deforestation, which is the core challenge PANDRILLUS FOUNDATION is attempting to resolve. Eight items with index between $0.600-0.699$ (ranked $6^{\text {th }}-12^{\text {th }}$ ) were all concerned with sustainable forest and wildlife management. Practical approach/ procedure in the management of natural resources had only 3 items with index range of between $0.500-0.599$. Issues in in-situ wildlife conservation also had 3 of the profiled items with index between $0.400-0.499$. The list ranked item was Park Management Operation with index of 0.236 . The analysis revealed that the students received the basic environmental information which is the core to attitudinal change in forest resource management by indigenous forest community dwellers that see such resources as nature's blessing to be exploited (DANIEL et al., 2016).

Table 2: Areas of Extended Conservation Education by PANDRILLUS FOUNDATION to Students

\begin{tabular}{llll}
\hline Items & Extended Topics on Conservation & Index & RROP \\
\hline 1 & Wildlife Management & $0.662^{\mathrm{b}}$ & $8^{\text {th }}$ \\
2 & & & \\
& Training on Natural Resources Management Protection/Conservation. & $0.548^{\mathrm{c}}$ & $15^{\text {th }}$ \\
3 & Conservation Status of different Species of Wildlife & $0.611^{\mathrm{b}}$ & $12^{\text {th }}$ \\
4 & Wildlife Protection Laws & $0.376^{\mathrm{e}}$ & $19^{\text {th }}$ \\
5 & Safety Precaution for Animals & $0.401^{\mathrm{d}}$ & $18^{\text {th }}$ \\
6 & Effects of Hunting & $0.631^{\mathrm{b}}$ & $9^{\text {th }}$ \\
7 & Environmental Protection & $0.682^{\mathrm{b}}$ & $6^{\text {th }}$ \\
8 & Impact of Deforestation & $0.790^{\mathrm{a}}$ & $1^{\text {st }}$ \\
9 & Global Warming & $0.745^{\mathrm{a}}$ & $5^{\text {th }}$ \\
10 & Park Management Operation & $0.236^{\mathrm{f}}$ & $20^{\text {th }}$ \\
11 & Management of Zoological Garden & $0.484^{\mathrm{d}}$ & $17^{\text {th }}$ \\
12 & Waste Management & $0.497^{\mathrm{d}}$ & $16^{\text {th }}$ \\
13 & Tree Nursery Establishment & $0.624^{\mathrm{b}}$ & $10^{\text {th }}$ \\
14 & Soil Conservation Technique & $0.586^{\mathrm{c}}$ & $14^{\text {th }}$ \\
15 & Plantation Establishment & $0.669^{\mathrm{b}}$ & $7^{\text {th }}$ \\
16 & Agroforestry & $0.790^{\mathrm{a}}$ & $1^{\text {st }}$ \\
17 & Afforestation (Enrichment planting) & $0.790^{\mathrm{a}}$ & $1^{\text {st }}$ \\
18 & Effects of Forest Fires & $0.618^{\mathrm{b}}$ & $11^{\text {th }}$ \\
19 & Pasture Establishment and Management & $0.611^{\mathrm{b}}$ & $12^{\text {th }}$
\end{tabular}




\section{Influence of Conservation Education on the Attitudinal Disposition of the Respondents}

On the attitudinal deposition of the respondents to career in conservation related discipline, Table 3 reveals that the conservation education (CE) programme of PANDRILLUS FOUNDATION has a positive impact on over $75 \%$ of the respondents who declared that the FOUNDATION activities has improved their knowledge of wildlife and natural conservation. The study reveals that a greater percentage $(99.4 \%)$ of the respondents would like to take up a career in conservation related discipline as they grow up. Environmental management, Forestry, Horticulture and landscaping, Veterinary medicine, and Wildlife conservation/management, had well above $50 \%$ embrace by the respondents (Table 4). The above results corroborate assertions by STORKSDIECK et al., (2005), Kruse and Card (2010), Bjerke et al., (1998), Morgan and Gramann (1989), KIDEGHESHO et al., (2007) and KERLLERT and BERRY (1987). They had in various ways asserted that positive outcome occurred on readiness to embrace conservation as a result of education advocacy.

Table 3: Deposition of Respondents on Impact Profile of PANDRILLUS FOUNDATION Activities

\begin{tabular}{llcc}
\hline $\mathbf{S} / \mathbf{N}$ & Variable & Frequency & Percentage \\
\hline 1. & Improvement of Respondent's Knowledge on CE & & \\
& Yes & 125 & 79.6 \\
& No & 32 & 20.4 \\
2. & Propensity to take up career in Conservation related & & \\
& discipline & & 99.4 \\
& Yes & 156 & 0.6
\end{tabular}

Note: $\mathrm{N}=157 ; \mathrm{RROP}=$ Relative Rank Order Positioning

Table 4: Incidence of Disposition on Career Acceptance

\begin{tabular}{llll}
\hline S/N & Possible Future Career Area & Index & RROP \\
\hline 1 & Forestry & 0.548 & $3^{\text {rd }}$ \\
2 & Horticulture and Landscaping & 0.637 & $2^{\text {nd }}$ \\
3 & Wildlife Conservation/ Management & 0.510 & $5^{\text {th }}$ \\
4 & Zoology & 0.414 & $6^{\text {th }}$ \\
5 & Pollution Control & 0.299 & $7^{\text {th }}$ \\
6 & Veterinary Medicine & 0.529 & $4^{\text {th }}$ \\
7 & Environmental Management & 0.662 & $15^{\text {th }}$ \\
8 & Agroforestry & 0.248 & $8^{\text {th }}$ \\
9 & Botany & 0.191 & $9^{\text {th }}$ \\
\hline
\end{tabular}

Note: $\mathrm{N}=157 ; \mathrm{RROP}=$ Relative Rank Order Positioning

\section{CONCLUSION}

There is a high profile on conservation education awareness by respondents. Thus, PANDRILLUS FOUNDATION and its partners could be adjudged to have made reasonable progress with respect to the goal of having an informed and involved citizenry on important matters of wildlife conservation.

Citizenry tends to understand the value of wildlife resources and appreciate the conservation and management of their natural resources when they are well informed. The level of conservation education advocacy has positively influence the youth's disposition towards choosing career in environmental management. It is obvious the relative outcomes of the PANDRILLUS can be strengthened if institutions, Organizations (Community Based, Governmental or NonGovernmental) and agencies involve in environmental management should develop environmental extension education programme as activities to its operational area as means of promoting effective mass delivery of messages. Combination of methods should be employed such as the use of audio-visual equipment to communicate, engage students in practical aspect of conservation so as to spore their career interest in the discipline. Lastly, evaluation of conservation programmes which is often overlooked is necessary to understand whether the target audiences are effectively impacted.

\section{REFERENCES}

Agbor, C. O. (2003). An ecological basis for the management of Afi Mountain Wildlife Sanctuary, Cross River State. Unpublished Ph.D. Thesis 
submitted to Department of Wildlife and Fisheries Management, University of Ibadan. 210pp.

Bjerke, T., Reitan, O., and Kellert, S. R. (1998). Attitudes towards Wolf in Southern Norway. Society and Natural Resources, 11, $169-178$.

Daniel, K. S.; Akachwuku, C. O. and Olajide, O. (2016). Communal Disposition to the Values of Sacred Groves in Southern Nigeria. Journal of Forestry, Environment and Sustainable Development. 2 (2): $58-68$.

Daye D. D. and Healey, J. R. (2015). Impact of LandUse Change on Sacred Forest at the Landscape Scale. Global Ecology and Conservation. 3: 349 358.

Ezebilo, E. E. (2010). Nature Conservation in a Tropical Rainforest: Economic, Local Particpation and Sustainability. Doctoral Thesis No. 2010:60. Acta Unviversitatis Agriculturae Sueciae. 66pages.

Ewah, J. O. (2010). Expanding mandate and corporate social responsibility in the management of national parks and protected areas in Nigeria. Journal of Agriculture and Environment for International Development 2010.104 (1-2):25-38.

http://www.fs.Usda.gov/conservationeducation. Retrieved 13/01/2015.

http://en.wikipedia.org/wiki/agricultural_extension:

Agricultural extension. Retrieved: 19/09/2014.

Ituen, E. E. (2015): Wildlife Extension Impact of PANDRILLUS FOUNDATION on Schools in Boki LGA, Cross River State. An Undergraduate Research Project submitted to the Department of Forestry and Wildlife, University of Uyo.

Kerllert, S. R. and Berry, J. K. (1987). Attitudes, Knowledge and Behaviours toward Wildlife as affected by Gender. Wildlife Society Bulletin, $154,363-371$.

Kideghesho, J. K., Roskaft, E. and Kaltenborn, B. P. (2007). Factors Influencing Attitudes of Local People in Western Serengti, Tanzania. Biodiversity and Conservation, p16, 2213-2230.
Kruse, C. K. and Card, J. A. (2004). Effects of a Conservation Education Camp Program on Campers' Self-Reported Knowledge, Attitude, and Behavior. Journal of Conservation Education. 35, 33-45. http://dx.doi.org/10.3200/JOEE.35.4.33-45.

Mbugua, P. (2012). Wildlife Conservation Education. In: The George Wright Forum, Vol. 29, No. 1, pp. 5966.

Morgan, J. M. \& Gramann, J. H. (1989). Predicting effectiveness of wildlife education programs: A study of students' attitudes and knowledge toward Snakes. Wildlife Society Bulletin, 17 (4):501-509.

National Population Commission (2006). Population Census figures for Cross River State, Nigeria.

Oates, John F. (1999). Myth and Reality in the Rainforest: How Conservation Strategies are failing in West Africa. Berkeley: University of California Press.

Oates, John. F. (2003). Gorilla Biology: A Multidisciplinary Perspective. Cambridge. Pp. 472497.

Pandrillus Foundation (2008). African conservation foundation. Available at http://www.africanconservation.org/pandrillusfoundation-2. Retrieved: 21/10/2014.

Primack, R. B. (2010). Essentials for Conservation Biology. Sunderland.

Stone R. D. And DÁndrea, C. (2001). Tropical Forest and the Human Spirit: Journey to the Brink of Hope. London, University of California.

Storksdieck, M., Ellenbogen, K., and Heimlich, J. (2005). Changing Minds? Reassessing outcomes in freechoice Environmental Education. Journal of Environmental Education Research. 11(3), 353 369. http://dx.doi.org/10.1080/13504620500081228.

Thompson, J. A. (2002). Review of the Status and Trends of and Major Threats to the Forest Biological Diversity. Montreal. SCBD. 16pages (CBD Technical series No. 7). 